\title{
The Role of Mobile Protons in Negative Ion CID of Oligosaccharides
}

\author{
Joseph Zaia, May Joy C. Miller, Jennifer L. Seymour, \\ and Catherine E. Costello \\ Department of Biochemistry, Mass Spectrometry Resource, Boston University School of Medicine, Boston, \\ Massachusetts, USA
}

Carbohydrates of all classes consist of glycoform mixtures built on common core units. Determination of compositions and structures of such mixtures relies heavily on tandem mass spectrometric data. Analysis of native glycans is often necessary for samples available in very low quantities and for sulfated glycan classes. Negative tandem mass spectrometry (MS) provides useful product ion profiles for neutral oligosaccharides and is preferred for acidic classes. In previous work from this laboratory, site-specific influences of sialylation on product ion profiles in the negative mode were elucidated. The present results show how the interplay of two other acidic groups, uronic acids and sulfates, determines product ion patterns for chondroitin sulfate oligosaccharides. Unsulfated chondroitin oligosaccharides dissociate to form C-type ions almost exclusively. Chondroitin sulfate oligosaccharides produce abundant B- and Y-type ions from glycosidic bond cleavage with C-and Z-types in low abundances. These observations are explained in terms of competing proton transfer reactions that occur during the collisional heating process. Mechanisms for product ion formation are proposed based on tandem mass spectra and the abundances of product ions as a function of collision energy. (J Am Soc Mass Spectrom 2007, 18, 952-960) (c) 2007 American Society for Mass Spectrometry

$\mathrm{T}$ The development of tandem mass spectrometric methods for glycomics requires clear understanding of glycan fragmentation mechanisms. Released glycans are heterogeneous with regard to presence of acidic residues or modifying groups. Such acidic moieties strongly influence the energetics of fragmentation and the patterns of tandem mass spectrometric product ion formation. Glycosaminoglycans (GAGs) consist of repeating disaccharide units, several classes of which are sulfated. Oligosaccharides of composition $(\text { Gal6X } \beta 4 \text { GlcNAc6S } \beta 3)_{n}$ where $\mathrm{X}=\mathrm{H}$ or $\mathrm{SO}_{3} \mathrm{H}$ and $\mathrm{S}=$ $\mathrm{SO}_{3} \mathrm{H}$ (derived from keratan sulfate), dissociate for form abundant A-type cross-ring cleavages to the reducing terminal residue [1, 2]. Oligosaccharides of composition $\Delta(\text { HexA } \beta 3 \text { GalNAc4/6S })_{n}$ (derived from chondroitin sulfate, CS) produce B- and Y-type ions [3-7], the pattern of which depends on the charge state [8]. Those of composition $\Delta(\operatorname{HexA} 2 \mathrm{X} \alpha / \beta 4 \mathrm{GlcNY} 6 \mathrm{Z})_{\mathrm{n}}$ where $\mathrm{X}$, $\mathrm{Z}=\mathrm{H}$ or $\mathrm{SO}_{3} \mathrm{H}$ and $\mathrm{Y}=\mathrm{Ac}, \mathrm{H}$, or $\mathrm{SO}_{3} \mathrm{H}$ (derived from heparan sulfate) produce a complex mixture of A-, B-, $\mathrm{C}_{-}, \mathrm{X}-, \mathrm{Y}-$, and Z-type product ions [9-12]. The goal of this work is to describe mechanisms behind the formation of negative product ions for GAG oligosaccharides.

Published online March 23, 2007

Address reprint requests to Dr. Joseph Zaia, Boston University School of Medicine, 670 Albany St., Rm. 509, Boston, MA 02118, USA. E-mail: jzaia@bu.edu
Nonsulfated native glycans dissociate in the positive mode to form abundant ions via glycosidic cleavages of the B- and Y-types, resulting from association of a cation with the glycosidic oxygen atom [13-15]. The most facile cross-ring cleavages are those to 4- or 6-linked reducing terminal residues [16-18]. Although cross-ring cleavage ions are abundant for 4-linked reducing terminal residues, those within internal branching residues have significantly lower abundances $[19,20]$. Sialic acids and sulfate groups are eliminated readily in the positive mode, resulting in the loss of information [21]. In the negative mode, neutral glycans produce abundant C-type ions, and cross-ring cleavages are observed within reducing terminal residues and to internal 4-linked residues [22-26]. Three-linked residues undergo double $\mathrm{C} / \mathrm{Z}$ (D-type) cleavage, providing useful information on glycan structure [23]. Sialic acid groups, when present, dramatically increase the energy required for precursor ion dissociation in the negative mode and decrease the abundances of $\mathrm{A}$ - and D-type ions [27].

Negative ions generated from CS oligosaccharides fragment to form B- and Y-type ions [4, 8], in contrast to the C- and Z-type ions observed for deprotonated neutral carbohydrates. In this regard, the types of glycosidic bond cleavages observed are similar to those for cationized oligosaccharides in the positive mode [28-31]. CS oligosaccharides contain 3-linked reducing end GalNAc residues and do not form A-type cross- 
ring cleavage ions as primary fragments. These oligosaccharide ions undergo ${ }^{0,2} \mathrm{X}$-type cleavage to the nonreducing $\Delta$-unsaturated uronosyl ring through a relatively facile retro-Diels-Alder mechanism [32].

This brief literature summary demonstrates that negatively charged oligosaccharide ions fragment differently depending on the presence or absence of acidic groups. Effective use of tandem mass spectrometric data to determine detailed structural information depends on understanding the mechanisms by which acidic groups influence the pattern of product ions formed. This study examines the roles of mobile protons in oligosaccharide negative mode tandem mass spectrometric fragmentation pathways. The influence of NeuAc residues in the product ion patterns for milk and $N$-linked oligosaccharides have been described recently [27]. The $^{\circ}$ roles $^{\circ}$ of $^{\circ}$ uronic $^{\circ}$ acids $^{\circ}$ in $^{\circ}$ product $^{\circ}$ ion patterns of CS glycosaminoglycan oligosaccharides will be examined here. The results are rationalized in terms of the energetic nature of the ions created during the electrospray process and in terms of the role of acidic protons in glycosidic bond cleavages. Practical implications for the design of tandem mass spectrometric platforms for comparative glycomics are discussed.

\section{Experimental}

CS type A, chondroitin, and chondroitinase enzymes were obtained from Seikagaku Associates of Cape Cod (Falmouth, MA). Testicular hyaluronidase (bovine) was obtained from Worthington Enzymes (Lakewood, NJ). CS 4,5-unsaturated disaccharides $\Delta$ HexA $\beta 3$ GalNAc4S $(\Delta \mathrm{Di} 4 \mathrm{~S})$ and $\Delta$ HexA $\beta 3$ GalNAc6S $(\Delta \mathrm{Di} 6 \mathrm{~S})$ were purchased from Seikagaku Associates of Cape Cod. CS saturated disaccharide GlcA 33 GalNAc4S (Di4S) was purchased from V-Labs, Inc. (Covington, LA).

\section{Enzymatic Digestions}

$\Delta$ HexA $\beta 3$ GalNAc4S $\beta 4$ GlcA $\beta 3 G a l N A c 4 S$ ( $\Delta$ Di4SDi4S) was prepared by depolymerization of CS type A using chondroitinase ACI. $\Delta$ HexA $\beta 3$ GalNAc $\beta 4$ GlcA $\beta 3$ GalNAc $(\triangle \mathrm{DiOSDiOS})$ was prepared by depolymerization of chondroitin with chondroitinase ACI. CS or chondroitin $(100 \mu \mathrm{g})$ was digested with chondroitinase ACI (5 mU) in tris- $\mathrm{HCl}$ buffer (75 mM, $\mathrm{pH} 7.4)$ containing ammonium acetate $(25 \mathrm{mM})$ for $5 \mathrm{~min}$ at $37^{\circ} \mathrm{C}$. The mixture was boiled for $1 \mathrm{~min}$ and then fractionated using a Superdex peptide 3.2/30 column (Amersham Biosciences, Piscataway, NJ) using the mobile phase $0.1 \mathrm{M}$ ammonium acetate, $10 \%$ acetonitrile at a flow rate of $100 \mu \mathrm{L} / \mathrm{min}$. Collected fractions were dried in vacuo. GlcA $\beta 3$ GalNAc $4 S \beta 4$ GlcA $\beta 3$ GalNAc4S (Di4SDi4S) was prepared by depolymerization of CS type A using testicular hyaluronidase. CS (100 $\mu \mathrm{g})$ was digested with testicular hyaluronidase $(2 \mu \mathrm{g})$ in tris- $\mathrm{HCl}$ buffer (75 mM, pH 7.4) for $36 \mathrm{~h}$ at $37^{\circ} \mathrm{C}$ and separated using the Superdex peptide column as above.

\section{Methyl Esterification}

Dry samples were dissolved in $0.5 \mathrm{M}$ methanolic $\mathrm{HCl}$ from freshly opened ampoules (Sigma Chemical Company, St. Louis, MO) and the solutions were kept at ambient temperature for $30 \mathrm{~min}$ before drying in vacuo. Samples were dissolved in 30\% methanol and analyzed directly using negative ion nano-electrospray MS. Tan$\operatorname{dem}^{\circ} \operatorname{mass}^{\circ}$ spectra $^{\circ}$ of $^{\circ} \operatorname{disaccharide}^{\circ}$ products $^{\circ}\left(\right.$ Figures $^{\circ} 1$ and $\left.{ }^{\circ} 2\right)^{\circ}$ were $^{\circ} \operatorname{consisten}^{\circ}{ }^{\circ}$ with $^{\circ}$ the $^{\circ}$ formation ${ }^{\circ}$ of $^{\circ}$ methyl esterified methylglycosides. Tandem mass spectra of tetrasaccharide ${ }^{\circ}$ products $^{\circ}\left(\text { Figures }^{\circ} 3,^{\circ} 4{ }^{\circ} \text { and }^{\circ} 5\right)^{\circ}$ were consistent with formation of molecules with two methyl esterified uronic acid residues and unmodified reducing ends.

\section{Electrospray Quadrupole Orthogonal Time-of-Flight Mass Spectrometry}

Mass spectra were acquired in the negative ion mode using an Applied Biosystems/MDS-SCIEX API QSTAR Pulsar-I quadrupole orthogonal time-of-flight mass spectrometer. Samples were dissolved in water and diluted in sufficient volume of $30 \%$ methanol to achieve a $1 \mathrm{pmol} / \mu \mathrm{L}$ solution. Aliquots $(3 \mu \mathrm{L})$ were infused into the mass spectrometer ion source using 1 to $2 \mu \mathrm{m}$ orifice nanospray ${ }^{\circ}[33]^{\circ}$ tips $^{\circ}$ pulled $^{\circ}$ from $^{\circ}$ thin-wall ${ }^{\circ}$ borosilicate glass capillaries $(1.2 \mathrm{~mm}$ o.d., $0.90 \mathrm{~mm}$ i.d.; World Precision Instruments, Sarasota, FL) using a Sutter Instrument P 80/PC micropipette puller (San Rafael, CA). Steady ion signal was typically observed using a needle potential of $-1000 \mathrm{~V}$ and all spectra were calibrated externally. For CID breakdown diagrams, the collision energy was set initially to $-5 \mathrm{~V}$ and stepped in $0.25 \mathrm{~V}$ increments to $-40 \mathrm{~V}$, with 0.5 to $1.0 \mathrm{~min}$ of acquisition per increment. Collision energies are expressed as their absolute values in the text and figures.

\section{Results and Discussion}

Figure $^{\circ} 1^{\circ}$ shows $^{\circ} \operatorname{tandem}^{\circ} \operatorname{mass}^{\circ}$ spectra $^{\circ}$ of $^{\circ}(\mathrm{a})^{\circ} \Delta \operatorname{Di}^{\circ} S^{\circ}$ and (b) methyl esterified $\Delta$ Di4S methyl glycoside $(\Delta \mathrm{Di} 4 \mathrm{~S}$ $\mathrm{ME})$, acquired using collision energy sufficient to reduce $^{\circ}$ the ${ }^{\circ}$ precursor ${ }^{\circ}$ ion $^{\circ}$ abundance ${ }^{\circ} b y^{\circ} \sim 50 \%$. ${ }^{\circ}{ }^{\circ}$ Figure 1a, ${ }^{\circ} \Delta$ Di4S ${ }^{\circ}$ produces both ${ }^{\circ}{ }^{\circ}$ glycosidic bond ${ }^{\circ}$ cleavageion $\left(\mathrm{Y}_{1}\right)$ and a cross-ring cleavage $\left({ }^{0,2} \mathrm{X}_{1}\right)$ in high abundance. $\mathrm{The}^{\circ} \Delta \mathrm{Di}^{\circ} \mathrm{S}^{\circ} \mathrm{ME}^{\circ}$ (Figure $1 \mathrm{~b}$ ) ${ }^{\circ}$ produces ${ }^{\circ}$ significantly ${ }^{\circ}$ lower abundances of ions from glycosidic bond cleavage $\left(Y_{1}\right)$ and the most abundant product ion corresponds to ${ }^{0,2} \mathrm{X}_{1}$ cross-ring ${ }^{\circ}$ cleavage. ${ }^{\circ}$ Figure ${ }^{\circ} 1 c^{\circ}$ shows ${ }^{\circ}$ the ${ }^{\circ}$ major ${ }^{\circ}$ product ions formed for the $\Delta \mathrm{Di} 4 \mathrm{~S}$ disaccharide in diagram form. Ions that are abundant for native precursors are drawn above the structure, and those for methyl esterified ${ }^{\circ}$ precursors ${ }^{\circ}$ below.$^{\circ}$ Figure $^{\circ} 1 \mathrm{~d}^{\circ}$ shows ${ }^{\circ}$ plots ${ }^{\circ}$ of ${ }^{\circ}$ precursor percent total ion abundances versus collision energy, for native and methyl esterified $\Delta \mathrm{Di} 4 \mathrm{~S}$. Significantly more collision energy is required to reduce the precursor ion abundances by $50 \%$ (16.5 versus $23.0 \mathrm{~V}$ ) after methyl esterification. The abundance of the ${ }^{0,2} X_{1}$ 


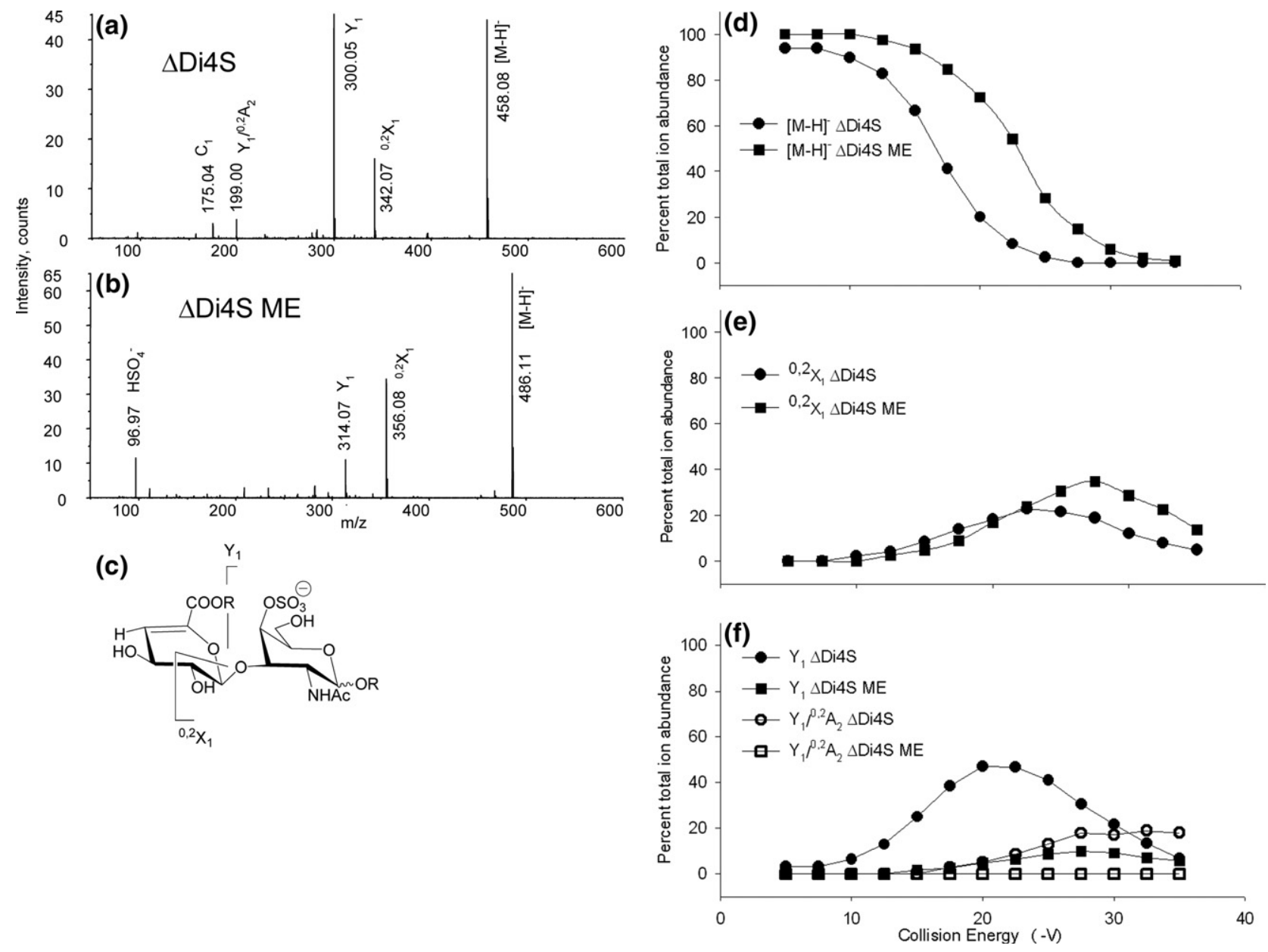

Figure 1. Tandem mass spectra of (a) $\Delta$ Di4S, CE $-17.5 \mathrm{~V}$; (b) $\Delta$ Di4S ME, CE $-22.5 \mathrm{~V}$. Trends in product ion formation are shown in (c). The product ions above the structures are abundant for native forms and those below for derivatized forms. $\mathrm{R}=\mathrm{H}$ for $\triangle \mathrm{Di} 4 \mathrm{~S}$ and $\mathrm{R}=\mathrm{CH}_{3}$ for $\triangle \mathrm{Di}$ S ME. CID breakdown diagrams for $(\mathbf{d})[\mathrm{M}-\mathrm{H}]^{-} \Delta \operatorname{Di} 4 \mathrm{~S}(\bullet)$ and $[\mathrm{M}-\mathrm{H}]^{-} \Delta \operatorname{Di} 4 \mathrm{SME}(\mathbf{\square}) ;(\mathbf{e})^{0,2} \mathrm{X}_{1} \Delta \operatorname{Di} 4 \mathrm{~S}(\bullet)$ and ${ }^{0,2} \mathrm{X}_{1} \Delta \operatorname{Di} 4 \mathrm{~S} \mathrm{ME}(\boldsymbol{\square}),(\mathbf{f}) \mathrm{Y}_{1} \Delta \operatorname{Di} 4 \mathrm{~S}(\bullet)$ and $\mathrm{Y}_{1} \Delta \operatorname{Di} 4 \mathrm{~S} \mathrm{ME}(\boldsymbol{\square}) ; \mathrm{Y}_{1} /{ }^{0,2} \mathrm{~A}_{2} \Delta \operatorname{Di} 4 \mathrm{~S}(\mathrm{O})$, and $\mathrm{Y}_{1} /{ }^{0,2} \mathrm{~A}_{2} \Delta \operatorname{Di} 4 S$ ME ( $\square)$.

cross-ring $^{\circ}{ }^{\circ}$ leavage ${ }^{\circ}$ ion ${ }^{\circ}$ increases ${ }^{\circ}\left(\text { Figure }^{\circ} 1 \mathrm{e}\right)^{\circ}$ for ${ }^{\circ} \Delta$ Di4S ME. The effect is significant, and is more pronounced for the 6-sulfated isomer, $\Delta$ Di6S (see Supplementary Figure 1 , which ${ }^{\circ}$ an be ${ }^{\circ}$ found in ${ }^{9}$ the ${ }^{\circ}$ electronic version of this article). The abundance of $Y_{1^{\circ}}\left(\text { Figure }^{\circ} 1 \mathrm{f}\right)^{\circ}$ decreases significantly, for $\triangle \mathrm{Di} 4 \mathrm{~S} \mathrm{ME}$. Thus, cross-ring cleavages become the primary fragmentation pathway for $\Delta \mathrm{Di} 4 \mathrm{~S}$ ME. The energy required for cross-ring cleavage increases ${ }^{\circ}$ only $^{\circ}{ }^{\circ}$ slightly ${ }^{\circ}$ for ${ }^{\circ} \Delta \operatorname{Di}^{\circ} \mathrm{S}^{\circ} \mathrm{ME}^{\circ}\left(\right.$ Figure $\left.^{\circ} 1 \mathrm{e}\right),{ }^{\circ}$ consistent with the hypothesis that the absence of competing processes accounts for the increasing relative abundances of ions that derive from cross-ring cleavages. Likely the $Y_{1}$ ion is formed by two processes: proton mediated glycosidic bond cleavage and secondary fragmentation of the ${ }^{0,2} X_{1}$ ion. For $\triangle \mathrm{Di} 4 \mathrm{~S} \mathrm{ME}$, the latter process is favored. This conclusion is supported by tandem MS of Di4S $[\mathrm{M}-\mathrm{H}]^{-}$, see below.

As ${ }^{\circ}$ shown ${ }^{\circ}{ }^{\circ}{ }^{\circ}$ igure ${ }^{\circ},{ }^{\circ}$ the ${ }^{\circ}$ tandem ${ }^{\circ}$ mass $^{\circ}$ spectrum ${ }^{\circ}$ of $\operatorname{Di}^{\circ} \mathrm{S}^{\circ}\left[\mathrm{M}^{\circ}-{ }^{\circ} \mathrm{H}\right]^{-}{ }^{\circ}$ ion, $^{\circ}\left(\right.$ Figure $\left.^{\circ} 2 \mathrm{a}\right),{ }^{\circ}$ differs $^{\circ}$ from $^{\circ}$ that ${ }^{\circ}$ of
$\Delta$ Di4S $[\mathrm{M}-\mathrm{H}]^{-}$in that the ${ }^{0,2} \mathrm{X}_{1}$ ion is absent, probably because the formation of cross-ring cleavage ions is disfavored by the saturated uronosyl ring. Specifically, the saturated uronosyl ring does not allow for formation of the ${ }^{0,2} X_{1}$ through the retro-Diels Alder mechanism [32]. Methyl ${ }^{\circ}$ esterified Di4S methylglycoside ${ }^{\circ}$ (Di4S ME, ${ }^{\circ}$ Figure $\left.{ }^{\circ} 2 \mathrm{~b}\right)^{\circ}$ produces $^{\circ}$ neither ${ }^{\circ}$ glycosidic $^{\circ}$ bond ${ }^{\circ}$ nor cross-ring cleavage ions in significant abundances. Replacement of the carboxyl proton with a methyl group evidently results in such stabilization of the glycosidic bond that formation of ions of composition $\left[\mathrm{HSO}_{4}\right]^{-}$ $\left(m / z\right.$ 96.97) and $\left[\mathrm{CH}_{3} \mathrm{SO}_{4}\right]^{-}(\mathrm{m} / \mathrm{z}$ 110.99) are more favored during the collisional heating process. The overall'trend in ${ }^{9}$ product ${ }^{\prime}$ ion formation is shown in'Figure 2c. The Di4S ME $[\mathrm{M}-\mathrm{H}]^{-}$ion requires increased collision energy, relative to Di4S $[\mathrm{M}-\mathrm{H}]^{-}$, to reduce the precursor ion abundance by $50 \%$ from 15.0 to $30.0 \mathrm{~V}$, as shown ${ }^{\circ}{ }^{\circ}$ Figure $2 \mathrm{~d}$ ). ${ }^{\circ}$ The ${ }^{\circ} Y_{1}$ ion undergoes subsequent fragmentation to form $\mathrm{Y}_{1} /{ }^{0,2} \mathrm{~A}_{2}$, a process that is favored 

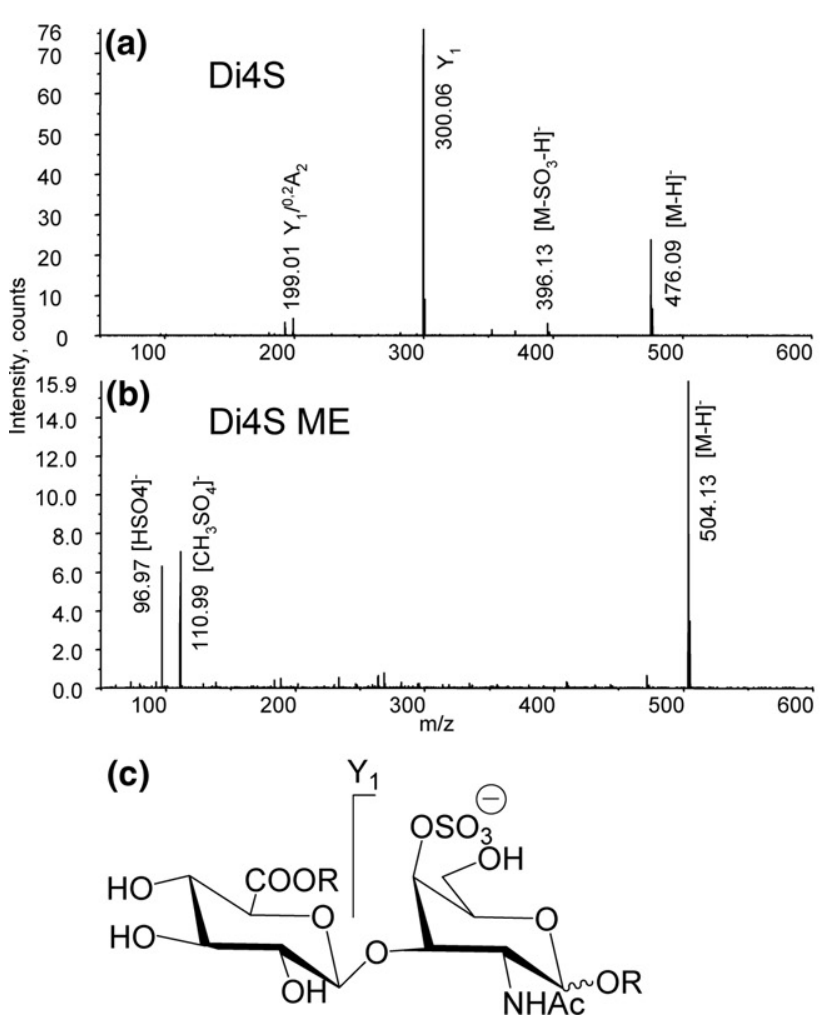
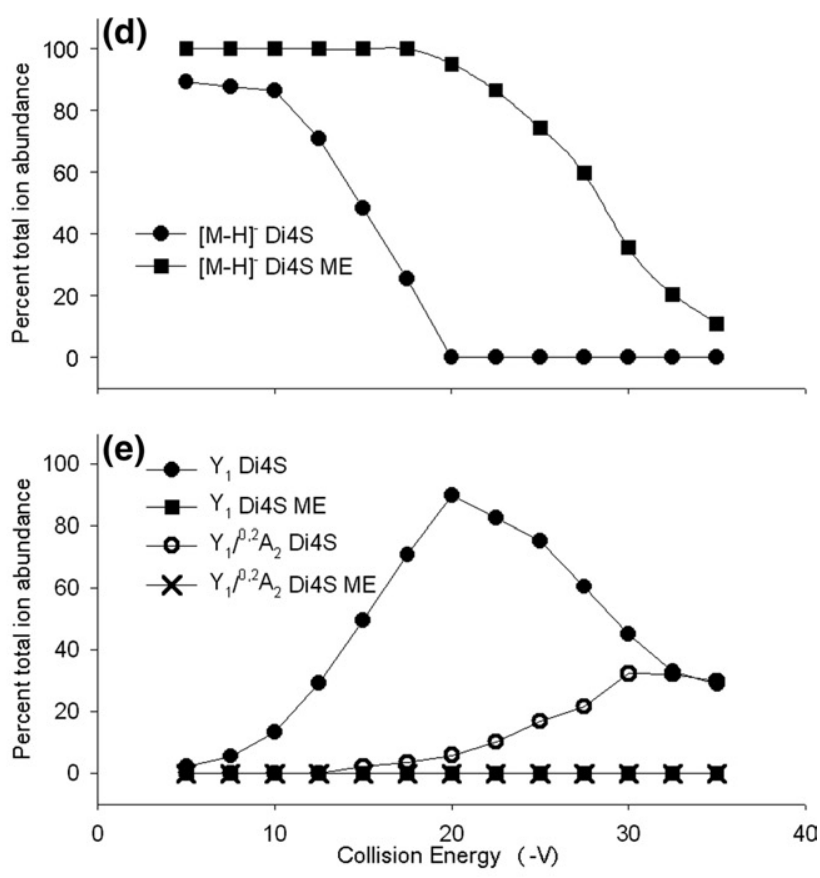

Figure 2. Tandem mass spectra of (a) Di4S, CE $-17.5 \mathrm{~V}$ and (b) Di4S ME, CE $-27.5 \mathrm{~V}$. Trends in product ion formation are shown in (c). The product ions above the structures are abundant for native forms and those below for derivatized forms. $\mathrm{R}=\mathrm{H}$ for Di4S and $\mathrm{R}=\mathrm{CH}_{3}$ for Di4S ME. CID breakdown diagrams for $(\mathbf{d})[\mathrm{M}-\mathrm{H}]^{-} \operatorname{Di} 4 \mathrm{~S}(\bullet)$ and $[\mathrm{M}-\mathrm{H}]^{-} \operatorname{Di} 4 \mathrm{~S} M E(\boldsymbol{\square}) ;(\mathbf{e}) \mathrm{Y}_{1} \operatorname{Di4S}(\boldsymbol{\bullet})$ and $\mathrm{Y}_{1}$ $\operatorname{Di4S} \operatorname{ME}(\boldsymbol{\square}), \mathrm{Y}_{1} / /^{0,2} \mathrm{~A}_{2} \operatorname{Di} 4 \mathrm{~S}(\mathrm{O})$, and $\mathrm{Y}_{1} /{ }^{0,2} \mathrm{~A}_{2} \operatorname{Di4S} \mathrm{ME}(\times)$.

at $^{\circ}{ }^{\circ}$ igher ${ }^{\circ}$ collision $^{\circ}$ energies, ${ }^{\circ}$ as $^{\circ}$ shown $^{\circ}$ in $^{\circ}$ Figure $^{\circ} 2$ e $^{\circ}$ The $^{\circ}$ formation of $\mathrm{Y}_{1}$ evidently enables ${ }^{0,2} \mathrm{~A}_{2}$ cleavage because the 3-position is no longer blocked. The Di4S ME forms neither $\mathrm{Y}_{1}$ nor $\mathrm{Y}_{1} /{ }^{0,2} \mathrm{~A}_{2}$, even at the highest collision energies.

Figure ${ }^{\circ}{ }^{\circ} \mathrm{Compares}^{\circ} \mathrm{CID}^{\circ}$ product $^{\circ}{ }^{\circ}{ }^{\circ}{ }^{\circ} \mathrm{mass}^{\circ}$ spectra $^{\circ}$ of (Figure $\left.^{\circ} 3 \mathrm{a}\right)^{\circ} \Delta$ Di4SDi4S $^{\circ}\left[\mathrm{M}^{\circ}-{ }^{\circ} 2 \mathrm{H}\right]^{2-{ }^{\circ}}$ and $^{\circ}\left(\right.$ Figure $^{\circ} 3 \mathrm{~b}$ ) methyl esterified $\triangle$ Di4SDi4S ( $\triangle$ Di4SDi4S ME) [M $2 \mathrm{H}]^{2-} .{ }^{\circ}$ The $^{\circ}$ most $^{\circ}$ abundant ${ }^{\circ}$ ions ${ }^{\circ}$ in $^{\circ}$ Figure $^{\circ} 3 \mathrm{a}^{\circ}$ are ${ }^{\circ}$ produced from cleavage of the reducing terminal glycosidic bond to form complementary $\mathrm{B}_{3}^{1-}$ and $\mathrm{Y}_{1}^{1-}$ ions.

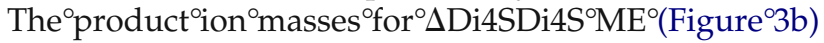
are consistent with the methyl esterification of both uronosyl residues and an unmodified reducing end. Methyl esterification dramatically changes the product ion pattern. The most abundant product ions are now ${ }^{0,2} X_{3}^{2-}$, followed by $Y_{3}^{2-}$, and ions of type $B$ are absent. As will be discussed in the next paragraph, the $\mathrm{Y}_{3}^{2-}$ and $\mathrm{Y}_{2}^{1-}$ ions are not observed for the saturated Di4SDi4S ME precursor ion. This precursor ion does not undergo ${ }^{0,2} \mathrm{X}$-type fragmentation due to the absence of a nonreducing end $\Delta$-unsaturated uronosyl ring. These observations are consistent with the conclusion that the $Y_{3}^{2-}$ and $Y_{2}^{1-}$ ions arise as sub-fragments of the ${ }^{0,2} X_{3}^{2-}$ cleavage for the $\triangle \mathrm{Di} 4 \mathrm{SD}$ i4S ME precursor. An abundant $\mathrm{C}_{3}$ ion is observed, indicating that methyl esterification has changed the probabilities for the competing frag- mentation pathways. Both the $\mathrm{Y}_{1}$ and $\mathrm{Y}_{1} /{ }^{0,2} \mathrm{~A}_{4}$ ions are absent in the tandem mass spectrum of $\triangle \mathrm{Di} 4 \mathrm{SDi}$ S $\mathrm{ME}$. The trend in product ion formation is shown diagrammatically ${ }^{\circ}$ in $^{\circ}$ Figure $^{\circ} 3 c^{\circ}{ }^{\circ}$ Methyl $^{\circ}$ esterification ${ }^{\circ}$ significantly increases the amount of energy required to reduce the precursor ion by $50 \%$ for the $\Delta$ Di 4 SDi $4 S$ (Figure $\left.{ }^{\circ} 3 \mathrm{~d}\right)^{\circ}$ from ${ }^{\circ} 12.5^{\circ}$ to ${ }^{\circ} 17.5^{\circ} \mathrm{V} .{ }^{\circ}$ The $^{\circ}$ abundance ${ }^{\circ}$ of ${ }^{\circ}$ the ${ }^{0,2} \mathrm{X}_{3}$ ion is very low at all collision energies for $\triangle$ Di4SDi4S, but it is significantly increased after methyl esterification $^{\circ}$ (Figure $^{\circ} 3 \mathrm{e}$ )..$^{\circ} \mathrm{As}^{\circ}$ shown $^{\circ}$ in $^{\circ}$ Figure $^{\circ} 3 \mathrm{f}^{\circ}{ }^{\circ}$ the abundances of the complementary $B_{3}$ and $Y_{1}$ ions are very low at all collision energies after methyl esterification, consistent with the carboxyl proton playing an important role in the formation B- and Y-type glycosidic cleavage ions. $\mathrm{A} \mathrm{C}_{3}$ ion is present for methyl esterified $\Delta$ Di4SDi4S but subsequent A-type cleavage to the internal GlcA residue is not observed. The series ${ }^{0,2} X_{3} \rightarrow Y_{3} \rightarrow Y_{2}$ is evidently the favored pathway. The fact that C-type ions are abundant only after methyl esterification is consistent with the conclusion that deprotonation of the anomeric hydroxyl group occurs during the collisional heating process. This process becomes favorable only when lower energy fragmentation ${ }^{\circ}$ pathways ${ }^{\circ}$ are ${ }^{\circ}$ blocked ${ }^{\circ} b^{\circ}{ }^{\circ}$ ethyl $l^{\circ}$ esterification.

The $^{\circ}$ native ${ }^{\circ}$ Di4SDi4S $\mathrm{S}^{\circ}\left[\mathrm{M}^{\circ}-{ }^{\circ} 2 \mathrm{H}\right]^{2-{ }^{\circ}}$ ion $^{\circ}\left(\right.$ Figure $\left.^{\circ} 4 \mathrm{a}\right)$ produces a pattern of glycosidic bond cleavage ions in which the ${ }^{0,2} X_{3}$ ion is absent. The methyl esterified 

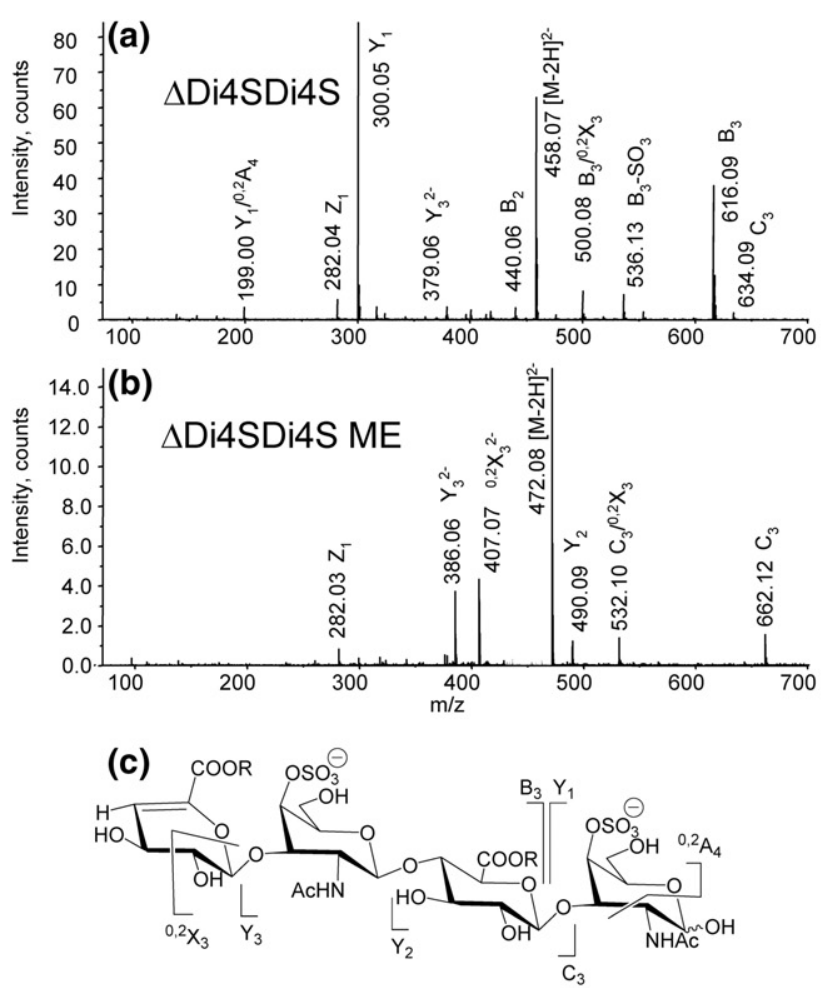
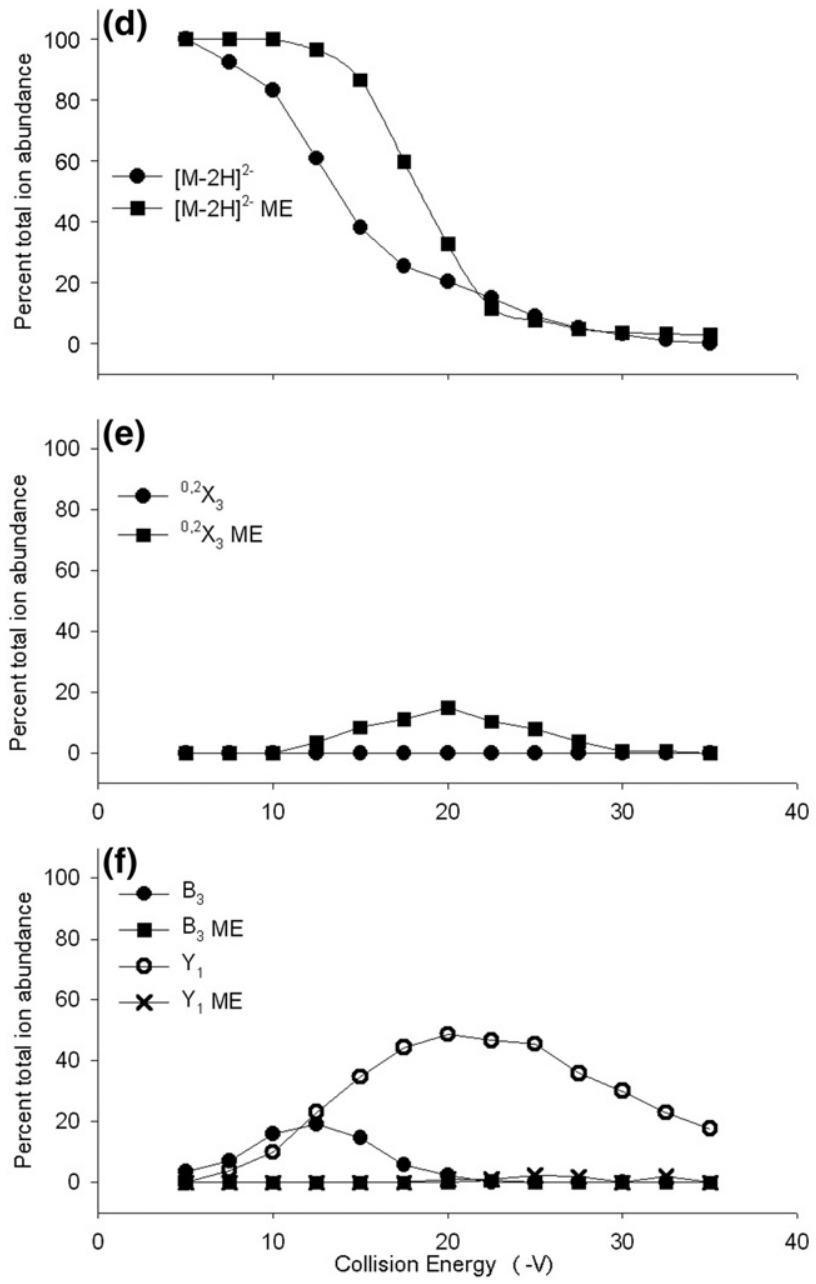

Figure 3. CID product ion mass spectra of (a) $\Delta$ Di4SDi4S $[\mathrm{M}-2 \mathrm{H}]^{2-}, \mathrm{CE}-15.0 \mathrm{~V}$ and (b) $\Delta \mathrm{Di} 4 \mathrm{SDi}$ S $\mathrm{ME}[\mathrm{M}-2 \mathrm{H}]^{2-}, \mathrm{CE}-17.5 \mathrm{~V}$. Trends in product ion formation are shown in (c). The product ions above the structures are abundant for native forms and those below for derivatized forms. $\mathrm{R}=\mathrm{H}$ for $\Delta$ Di4SDi4S and $\mathrm{R}=\mathrm{CH}_{3}$ for $\triangle$ Di4SDi4S ME. CID breakdown diagrams for $(\mathbf{d})[\mathrm{M}-2 \mathrm{H}]^{2-} \Delta \mathrm{Di} 4 \mathrm{SDi} 4 \mathrm{~S}$ (๑) and $[\mathrm{M}-2 \mathrm{H}]^{2-} \Delta \operatorname{Di} 4 S \operatorname{Si} 4 S \mathrm{ME}(\boldsymbol{\square}) ;(\mathbf{e})^{0,2} \mathrm{X}_{3} \Delta \operatorname{Di} 4 S \operatorname{Di} 4 \mathrm{~S}(\bullet)$ and ${ }^{0,2} \mathrm{X}_{3} \Delta \operatorname{Di4SDi4S} \mathrm{ME}(\boldsymbol{\square}) ;(\mathbf{f}) \mathrm{B}_{3}$

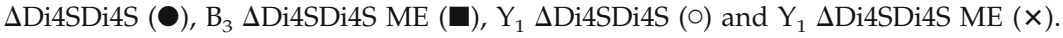

Di4SDi4S $^{\circ}$ precursor $^{\circ}\left(\text { Figure }^{\circ} 4 \mathrm{~b}\right)^{\circ}$ produces $^{\circ}$ an $^{\circ}$ abundant $\mathrm{C}_{3}$ ion but does not yield ${ }^{0,2} \mathrm{X}_{3}$ and $\mathrm{Y}_{3}$ ions. A-type product ions have been shown to arise from retro-aldol rearrangement of oligosaccharide ions in the negative mode $^{\circ}\left[16,{ }^{\circ} 17\right]^{\circ}{ }^{\circ}$ This $^{\circ}$ mechanism ${ }^{\circ}$ requires $^{\circ}$ an $^{\circ}$ open-ring reducing terminal aldehyde, and such structures are formed ${ }^{\circ}$ by $^{\circ} \mathrm{C}$-type ${ }^{\circ}$ fragmentation ${ }^{\circ}[23-25] .{ }^{\circ} \mathrm{The}^{\mathrm{o0,2}} \mathrm{A}_{3}$ ion formed from cross-ring cleavage to the internal GlcA residue $^{\circ}$ in $^{\circ} F_{i g u r e} 4 b^{\circ}{ }^{\circ} s^{\circ}$ therefore ${ }^{\circ}$ likely ${ }^{\circ} t^{\circ}{ }^{\circ}$ arise ${ }^{\circ}$ from ${ }^{\circ}$ the $\mathrm{C}_{3}$ ion by retro-aldol rearrangement. The results show that replacement of the carboxyl proton with a methyl group alters the product ion pathways by disfavoring formation of B- and Y-type ions and favoring A-type cleavage in the internal GlcA residue. The trends in product $^{\circ}$ ion ${ }^{\circ}$ formation ${ }^{\circ}$ are $^{\circ}$ illustrated ${ }^{\circ}$ in $^{\circ}$ Figure $^{\circ} 4 \mathrm{c}^{\circ}{ }^{\circ}$ As shown ${ }^{\circ}{ }^{\circ}{ }^{\circ}$ Figure $^{\circ} 4 \mathrm{~d}$, ${ }^{\circ}$ the ${ }^{\circ}$ amount ${ }^{\circ}$ of ${ }^{\circ}$ energy ${ }^{\circ}$ required ${ }^{\circ}$ to decrease the precursor ion abundance by $50 \%$ increased from 12.5 to $22.5 \mathrm{~V}$, due to methyl esterification. The formation of ${ }^{0,2} \mathrm{X}_{3}$ is not observed for Di4SDi4S, and the formation of $\mathrm{C}_{3}$ ions $^{\circ}$ is $^{\circ}$ observed $^{\circ}$ (Figure $\left.{ }^{\circ} 4 \mathrm{e}\right)$. These ${ }^{\circ}$ ions subsequently form ${ }^{0,2} A_{3}$ ions as the energy increases. The formation of $B_{3}$ and $Y_{1}$ ions is favorable only for native ${ }^{\circ}$ Di4SDi4S, ${ }^{\circ}$ as $^{\circ}$ shown $^{\circ}{ }^{\circ}{ }^{\circ}$ Figure $^{\circ} 4 f^{\circ} .^{\circ} I^{\circ}$ summary, native ions produce complementary B and Y-type glycosidic cleavages, and methyl esterified ions produce C- and A-type ions.

Unsulfated $\triangle$ DiOSDiOS dissociates as an $[\mathrm{M}-\mathrm{H}]^{-}$ ion to form an abundant series of C-type ions, as shown in ${ }^{\circ}$ Figure $^{\circ} 5 \mathrm{a} .{ }^{\circ}$ Ions $^{\circ}$ of $^{\circ}$ type $^{\circ} \mathrm{B}^{\circ}$ and ${ }^{\circ} Y^{\circ}$ are $^{\circ}$ observed ${ }^{\circ}$ in ${ }^{\circ}$ low abundances and are absent in the product ion profile of the $[\mathrm{M}-2 \mathrm{H}]^{2-}$ ion (not shown). The $\triangle \mathrm{DiOSDiOS} \mathrm{ME}$

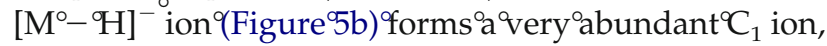
the $m / z$ of which (175.03) is consistent with an unmodified HexA residue. A low abundance $C_{2}$ ion with one methyl group is detected at $\mathrm{m} / \mathrm{z}$ 392.13. The product ions $^{\circ}$ formed $^{\circ}$ are $^{\circ}$ shown $^{\circ}$ diagrammatically ${ }^{\circ}$ in ${ }^{\circ}$ Figure $^{\circ} 5 \mathrm{c}$. Apparently rearrangement to lose a methyl group during the formation of the $C_{1}$ ion is the most facile 

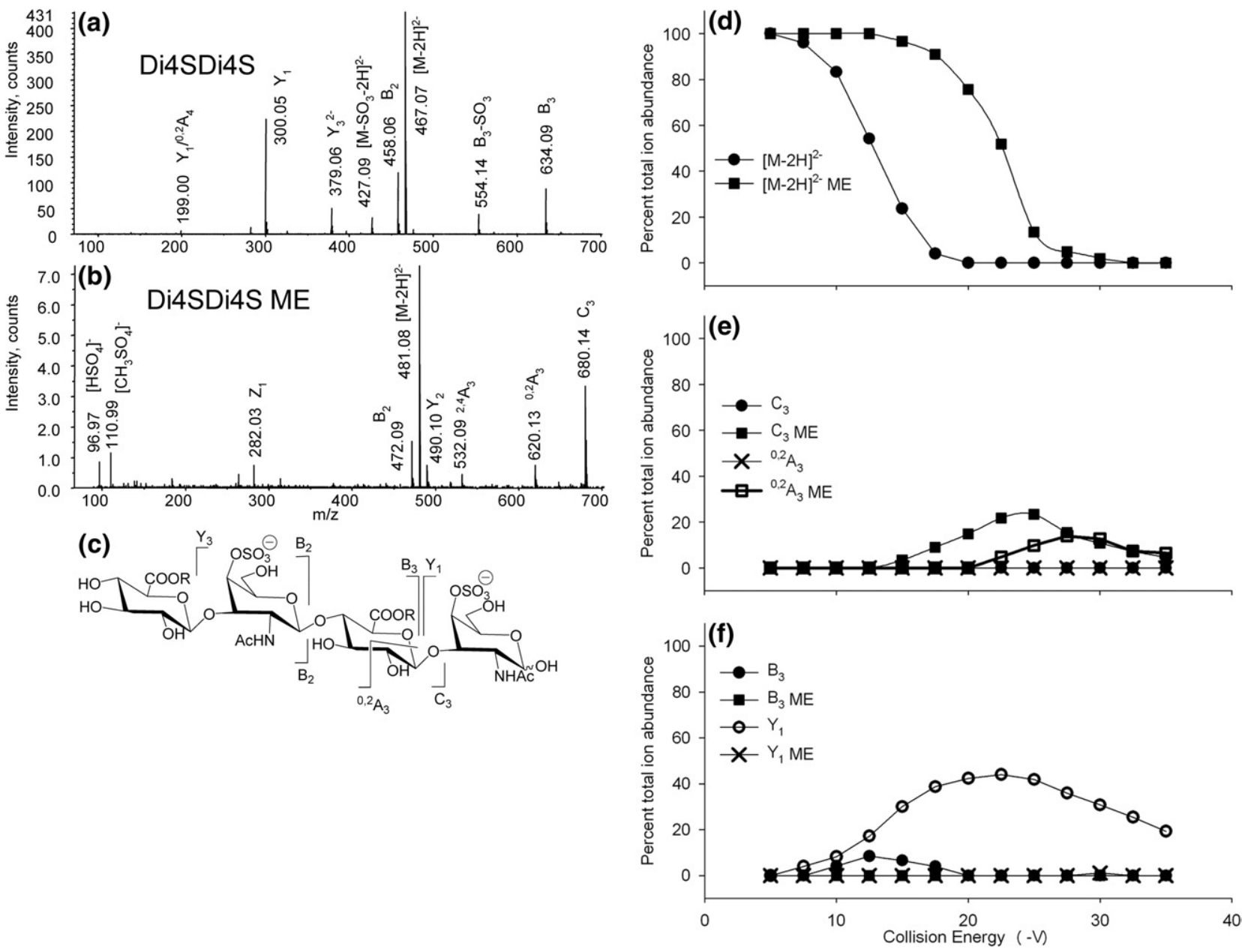

Figure 4. CID product ion mass spectra of (a) Di4SDi4S $[\mathrm{M}-2 \mathrm{H}]^{2-}, \mathrm{CE}-12.5 \mathrm{~V}$ and (b) Di4SDi4S ME, CE $-22.5 \mathrm{~V}$. Trends in product ion formation are shown in (c). The product ions above the structures are abundant for native forms and those below for derivatized forms. $\mathrm{R}=\mathrm{H}$ for Di4SDi4S and $\mathrm{R}=\mathrm{CH}_{3}$ for Di4SDi4S ME. CID breakdown diagrams for (d) $[\mathrm{M}-2 \mathrm{H}]^{2-}$

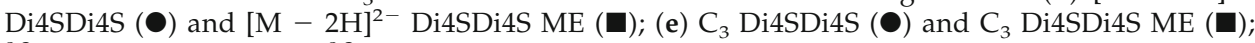

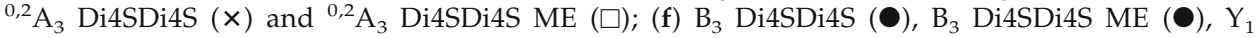
Di4SDi4S $(0)$ and $Y_{1}$ Di4SDi4S ME $(x)$.

fragmentation process for the methyl esterified molecular ion. In the absence of acidic groups, charge formation for the methyl esterified variant is likely to occur by deprotonation of a ring hydroxyl group. Such deprotonation results in an ion with significantly higher internal energy than that formed by deprotonation of an acidic group. As a result, fragmentation processes that require significantly higher energy become accessible.

The abundances of the $\triangle \mathrm{DiOSDiOS}$ precursor ions as $^{\circ}{ }^{\circ}{ }^{\circ}$ function ${ }^{\circ}$ of $^{\circ}$ collision $^{\circ}$ energy ${ }^{\circ}{ }^{\circ}{ }^{\circ}{ }^{\circ}$ plotted $^{\circ}{ }^{\circ}{ }^{\circ}$ Figure $5 \mathrm{~d}^{\circ}{ }^{\circ} \mathrm{The}^{\circ} \Delta \mathrm{DiOSDiOS}^{\circ}\left[\mathrm{M}^{\circ}-{ }^{\circ} \mathrm{H}\right]^{-}{ }^{\circ}$ ion $^{\circ}$ (filled ${ }^{\circ}$ circle) dissociates at significantly higher energies than does the $[\mathrm{M}-2 \mathrm{H}]^{2-}$ ion (filled square). Despite the significant differences in dissociation energies, the overall product ion patterns are similar. The $\Delta$ DiOSDiOS ME $[\mathrm{M}-\mathrm{H}]^{-}$ion requires the highest collision energy ${ }^{\circ}$ for ${ }^{\circ}$ dissociation. ${ }^{\circ}$ As ${ }^{\circ}$ shown in ${ }^{\circ}$ Figure 5 e, native $\triangle$ DiOSDiOS $[\mathrm{M}-\mathrm{H}]^{-}$dissociates to form a $\mathrm{C}_{2}$ ion (filled square) with maximum abundance at $17.5 \mathrm{~V}$.
Likely this ion dissociates again to form $C_{1}$ ions (filled circle). The $\mathrm{C}_{3}$ ion (filled triangle) is observed with maximum abundance at $27.5 \mathrm{~V}$, and may also undergo further fragmentation. The formation of the $C_{1}$ ion from the methyl esterified $\triangle \mathrm{DiOSDiOS}[\mathrm{M}-\mathrm{H}]^{-}$ precursor ion (open circle) occurs with maximum abundance at $37.0 \mathrm{~V}$. Likely this ion is formed by rearrangement of the ester methyl group at elevated energies.

Scheme 1 shows proposed mechanisms for fragmentation of CS GAG ions with unmodified reducing ends in the negative low-energy CID product ion mode. As shown in Scheme 1a, native CS oligosaccharides produce abundant B- and Y-type ions, with comparatively low abundances of $\mathrm{C}$ - and $\mathrm{X}$-type ions. For CS oligosaccharides of composition $\Delta(\operatorname{HexA})_{x}$ $(\mathrm{GalNAc})_{x}\left(\mathrm{SO}_{3}\right)_{x}$, the most abundant charge state observed using negative ion ESI is typically equal to $X$. For such charge states, the most abundant popu- 

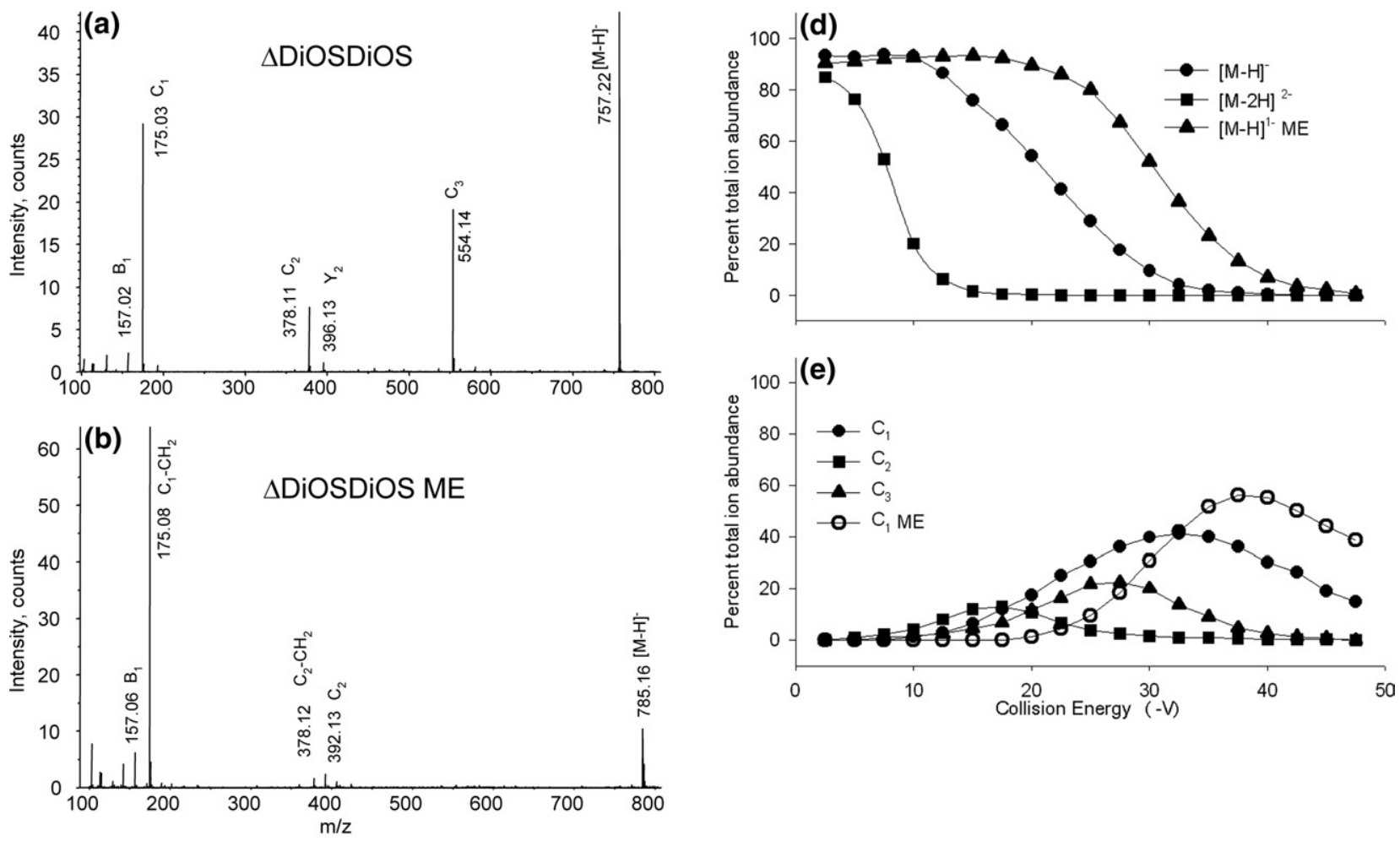

(c)

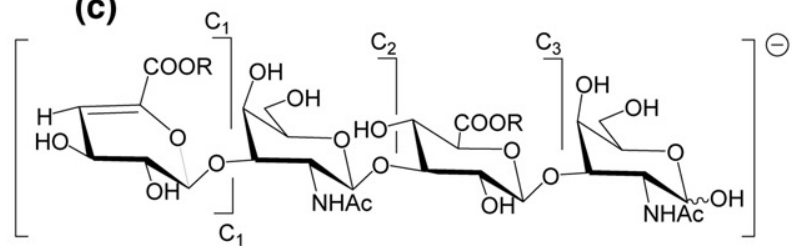

Figure 5. Tandem mass spectra of (a) $\Delta$ DiOSDiOS $[\mathrm{M}-\mathrm{H}]^{-}$at $\mathrm{CE}-22.5 \mathrm{~V}$, (b) $\Delta$ DiOSDiOS ME $[\mathrm{M}-\mathrm{H}]^{-}$at $\mathrm{CE}-37.5 \mathrm{~V}$. Trends in product ion formation are shown in (c). The product ions above the structures are abundant for native forms and those below for derivatized forms. $\mathrm{R}=\mathrm{H}$ for $\triangle$ DiOSDiOS and $\mathrm{R}=\mathrm{CH}_{3}$ for $\triangle$ DiOSDiOS ME. CID breakdown diagrams for (d) $\left[\mathrm{M}-\mathrm{H}^{-}\right.$ $\Delta \operatorname{DiOSDiOS}(\bullet),[\mathrm{M}-2 \mathrm{H}]^{2-} \Delta \operatorname{DiOSDiOS}(\mathbf{\square})$ and $[\mathrm{M}-\mathrm{H}]^{-} \Delta \operatorname{DiOSDiOS} \mathrm{ME}(\mathbf{\Delta}),(\mathbf{e}) \Delta \operatorname{DiOSDiOS}[\mathrm{M}$ $-\mathrm{H}]^{-} \mathrm{C}_{1}(\bullet), \mathrm{C}_{2}(\mathbf{\square}), \mathrm{C}_{3}(\mathbf{\Delta})$ and $\Delta \operatorname{DiOSDiOS} \mathrm{ME}[\mathrm{M}-\mathrm{H}]^{-} \mathrm{C}_{1}(\mathrm{O})$.

lation of precursor ions is one where each sulfate group is charged and the carboxyl groups are protonated. The observation of B- and Y-type ions is consistent with the conclusion that the carboxyl proton becomes delocalized during the collisional heating process and associates with a glycosidic oxygen atom. This association destabilizes the glycosidic bond in a manner similar to that described for oligosaccharides during ${ }^{\circ}$ positive ${ }^{\circ}$ mode $^{\circ} \mathrm{CID}^{\circ}\left[14,{ }^{\circ} 34\right]{ }^{\circ} .^{\circ}$ For ${ }^{\circ}$ methyl ${ }^{\circ}$ esterified CS GAG oligosaccharides (Scheme 1b), the carboxyl protons are replaced with methyl groups, and significantly more energy is required for fragmentation. The fact that abundant $\mathrm{C}_{3}^{1-}$ is observed for the methyl esterified $\triangle \mathrm{Di} 4 \mathrm{SDi}$ SS and Di4SDi4S ion is consistent with the deprotonation of a reducingterminal hydroxyl group with subsequent rearrangement to eliminate the reducing end residue as a neutral ${ }^{\circ}$ fragment ${ }^{\circ}[25]^{\circ}{ }^{\circ} S^{\prime}$ ch $^{\circ}{ }^{\circ}{ }^{\circ}$ event $^{\circ}{ }^{\circ}$ could $^{\circ}$ take ${ }^{\circ}$ place during collisional heating, as shown in (Scheme 1b). The lower basicity of the $\mathrm{SO}_{3}^{-}$group relative to $\mathrm{COO}^{-}$ explains the increased energy required to produce this rearrangement. The $\triangle \mathrm{DiOSDiOS}$ tetramer lacks sulfate groups and forms C-type ions for both 1-and 2-precursor ion charge states. This observation is consistent with the conclusion that the interplay between $\mathrm{COOH}$ and $\mathrm{SO}_{3}^{-}$groups is necessary for the observation of complementary B- and Y-type ion pairs. The data show that C-type ion formation is considerably more facile for $\triangle \mathrm{DiOSDiOS}$, consistent with the conclusion, as shown in (Scheme 1c), that a proton from a ring hydroxyl group to the carboxylate anion during the heating process. The formation of C-type ions from $\triangle \mathrm{DiOSDiOS}$ occurs at a lower energy because of the diminished barrier to transferring a proton to a carboxyl group. In summary, C-type ions are favored in the negative mode when either sulfate or carboxylate groups are present in the oligosaccharide structure. When both are present, the availability of a mobile proton results in formation of B- and Y-type ion pairs. 
(a) Native CS

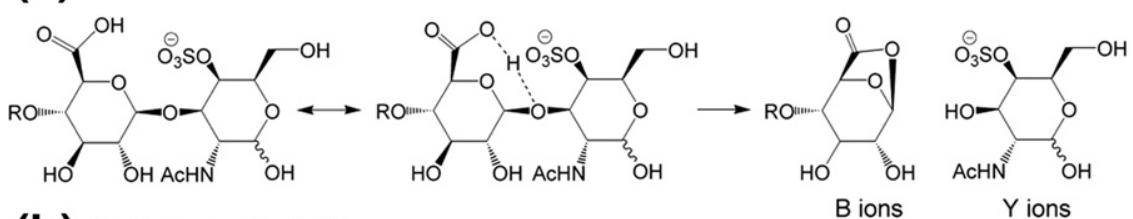

(b) Methyl esterified CS

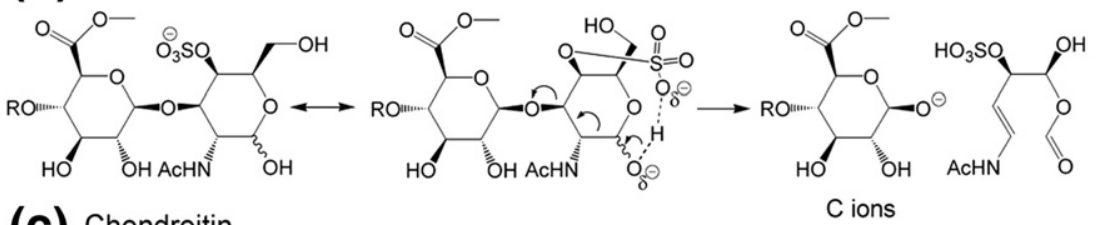

(c) Chondroitin

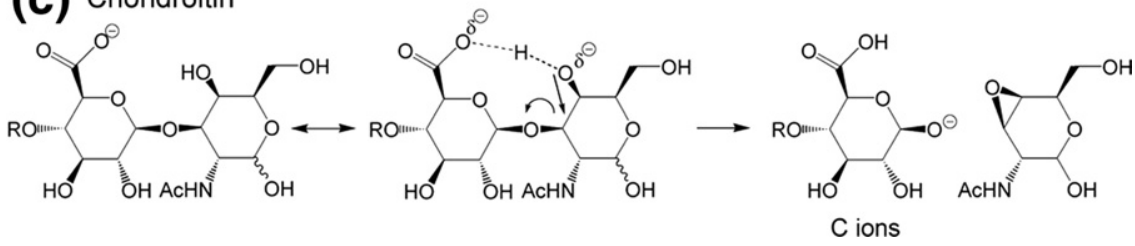

Scheme 1. Proposed mechanisms for formation low-energy negative ion CID product ions (a) B- and Y-type ions for oligosaccharides derived from CS with unmodified reducing ends, (b) C-type ions from methyl esterified oligosaccharides derived from CS, and (c) C-type ions from oligosaccharides derived from chondroitin.

\section{Conclusions}

It is useful to classify carbohydrates based on their acidic properties. Neutral glycans produce abundant C-type ions during negative dissociation. Sialylation dramatically increases the amount of energy necessary to induce fragmentation and, although many of the same ion types are observed, the abundances of crossring $^{\circ}$ cleavages $^{\circ}$ to $^{\circ}$ branching $^{\circ}$ residues $^{\circ}$ decreases $^{\circ}$ [27]. Sulfated oligosaccharides lacking other acidic groups produce abundant C-type ions but require still higher collision energies to induce fragmentation. The presence of sulfate and uronic acids together, however, results in formation of ions of B- and Y-types, in a pattern similar to that observed for glycans in positive ions tandem MS. This pattern is attributed here to the interplay between sulfate and carboxylate groups, resulting in the availability of protons that become mobilized during the dissociation process. It is notable that mobile protons play roles in peptide fragmentation, explaining the observation of enhanced backbone cleavages $^{\circ}$ adjacent ${ }^{\circ}$ to $^{\circ}$ acidic $^{\circ}$ amino $^{\circ}$ acid $^{\circ}$ residues $^{\circ}[35]$.

Because released glycans are composed of glycoform mixtures, the compositions of many of which are isomeric, it is essential to gain a clear understanding of the tandem mass spectra. This and earlier work demonstrate that conditions for product ion analysis depends strongly on the compound class. Differentiation of isomers based on tandem mass spectrometric product ion abundances depends on an accurate understanding of the mechanisms behind the formation of product ions. This entails (1) the use of collision energies appropriate for the glycan composition in question, and (2) accurate understanding of the variation of product ion abundances for different structural isomers. To analyze glycan mixtures successfully, it is essential to tailor the collision energy to the glycan composition. This argues for separation of mixtures based on acidities using graphitized carbon, normal phase, or anion exchange chromatography before on- or off-line tandem mass spectrometric analysis. The separation step facilitates the use of appropriate tandem mass spectrometric collision energies for each glycan compositional class. Attempts to use a single set of fragmentation parameters for all glycans present in an unfractionated mixture are likely to result in over-fragmentation of fragile ions and under-fragmentation of more robust species.

\section{Acknowledgments}

The authors gratefully acknowledge supported for this work by NIH grants P41RR10888 and R01HL74197.

\section{References}

1. Zhang, Y.; Kariya, Y.; Conrad, A. H.; Tasheva, E. S.; Conrad, G. W. Analysis of Keratan Sulfate Oligosaccharides by Electrospray Ionization Tandem Mass Spectrometry. Anal. Chem. 2005, 77, 902-910.

2. Oguma, T.; Toyoda, H.; Toida, T.; Imanari, T. Analytical Method for Keratan Sulfates by High-Performance Liquid Chromatography/ Turbo-Ionspray Tandem Mass Spectrometry. Anal. Biochem. 2001, 290, $68-73$.

3. Lamb, D. J.; Wang, H. M.; Mallis, L. M.; Linhardt, R. J. Negative Ion Fast-Atom Bombardment Tandem Mass Spectrometry to Determine Sulfate and Linkage Position in Glycosaminoglycan Derived Disaccharides. J. Am. Soc. Mass Spectrom. 1992, 3, 797-803.

4. Zaia, J.; McClellan, J. E.; Costello, C. E. Tandem Mass Spectrometric Determination of the 4S/6S Sulfation Sequence in Chondroitin Sulfate Oligosaccharides. Anal. Chem. 2001, 73, 6030-6039.

5. Desaire, H.; Sirich, T. L.; Leary, J. A. Evidence of Block and Randomly Sequenced Chondroitin Polysaccharides: Sequential Enzymatic Digestion and Quantification Using Ion Trap Tandem Mass Spectrometry. Anal. Chem. 2001, 73, 3513-3520. 
6. Zamfir, A.; Seidler, D. G.; Kresse, H.; Peter-Katalinc, J. Structural Characterization of Chondroitin/Dermatan Sulfate Oligosaccharides from Bovine Aorta by Capillary Electrophoresis and Electrospray Ionization Quadrupole Time-of-Flight Tandem Mass Spectrometry. Rapid Commun. Mass Spectrom. 2002, 16, 2015-2024.

7. Zamfir, A.; Seidler, D. G.; Schonherr, E.; Kresse, H.; Peter-Katalinic, J. On-line Sheathless Capillary Electrophoresis/Nanoelectrospray Ionization-Tandem Mass Spectrometry for the Analysis of Glycosaminoglycan Oligosaccharides. Electrophoresis 2004, 25, 2010-2016.

8. McClellan, J. M.; Costello, C. E.; O'Connor, P. B.; Zaia, J. Influence of Charge State on Product Ion Mass Spectra and the Determination of 4S/6S Sulfation Sequence of Chondroitin Sulfate Oligosaccharides. Anal. Chem. 2002, 74, 3760-3771.

9. Mallis, L. M.; Wang, H. M.; Loganathan, D.; Linhardt, R. J. Sequence Analysis of Highly Sulfated, Heparin-Derived Oligosaccharides Using Fast Atom Bombardment Mass Spectrometry. Anal. Chem. 1989, 61, 1453-1458.

10. Saad, O. M.; Leary, J. A. Compositional Analysis and Quantification of Heparin and Heparan Sulfate by Electrospray Ionization Ion Trap Mass Spectrometry. Anal. Chem. 2003, 75, 2985-2995.

11. Naggar, E. F.; Costello, C. E.; Zaia, J. Competing Fragmentation Processes in Tandem Mass Spectra of Heparin-Like Glycosaminoglycans. J. Am. Soc. Mass Spectrom. 2004, 15, 1534-1544.

12. Zaia, J.; Costello, C. E. Tandem Mass Spectrometry of Sulfated HeparinLike Glycosaminoglycan Oligosaccharides. Anal. Chem. 2003, 75, 24452455.

13. Orlando, R.; Bush, C. A.; Fenselau, C. Structural Analysis of Oligosaccharides by Tandem Mass Spectrometry-Collisional Activation of Sodium Adduct Ions. Biomed Environ. Mass Spectrom 1990, 19, 747-754

14. Hofmeister, G. E.; Zhou, Z.; Leary, J. A. Linkage Position Determination in Lithium-Cationized Disaccharides-Tandem Mass Spectrometry and Semiempirical Calculations. J. Am. Chem. Soc. 1991, 113, 5964-5970.

15. Ngoka, L. C.; Gal, J. F.; Lebrilla, C. B. Effects of Cations and Charge Types on the Metastable Decay Rates of Oligosaccharides. Anal. Chem. 1994, 66, 692-698.

16. Dallinga, J. W.; Heerma, W. Reaction Mechanism and Fragment Ion Structure Determination of Deprotonated Small Oligosaccharides, Studied by Negative Ion Fast Atom Bombardment (Tandem) Mass Spectrometry. Biol. Mass Spectrom. 1991, 20, 215-231.

17. Spengler, B.; Dolce, J. W.; Cotter, R. J. Infrared-Laser Desorption Mass-Spectrometry of Oligosaccharides-Fragmentation Mechanisms and Isomer Analysis. Anal. Chem. 1990, 62, 1731-1737.

18. Carroll, J.; Willard, D.; Lebrilla, C. Energetics of Cross-Ring Cleavages and Their Relevance to the Linkage Determination of Oligosaccharides. Anal. Chim. Acta. 1995, 307, 431-447.

19. Harvey, D. J.; Naven, T. J. P.; Küster, B.; Bateman, R. H.; Green, M. R. Critchley, G. Comparison of Fragmentation Modes for the Structural Determination of Complex Oligosaccharides Ionized by MatrixAssisted Laser Desorption Ionization Mass Spectrometry. Rapid Commun. Mass Spectrom. 1995, 9, 1556-1561.

20. Harvey, D. J.; Bateman, R. H.; Green, M. R. High-Energy CollisionInduced Fragmentation of Complex Oligosaccharides Ionized by Matrix-
Assisted Laser Desorption/Ionization Mass Spectrometry. J. Mass Spectrom. 1997, 32, 167-187.

21. Zaia, J. Mass Spectrometry of Oligosaccharides. Mass Spectrom. Rev. 2004, 23, 161-227.

22. Domon, B.; Costello, C. E. A Systematic Nomenclature for Carbohydrate Fragmentations in FAB-MS/MS Spectra of Glycoconjugates. Glycoconj. J. 1988, 5, 397-409.

23. Chai, W.; Piskarev, V.; Lawson, A. M. Negative-Ion Electrospray Mass Spectrometry of Neutral Underivatized Oligosaccharides. Anal. Chem. 2001, 73, 631-657.

24. Pfenninger, A.; Karas, M.; Finke, B.; Stahl, B. Structural Analysis of Underivatized Neutral Human Milk Oligosaccharides in the Negative Ion Mode by Nano-Electrospray MS ${ }^{n}$. Part 2. Application to Isomeric Mixtures. J. Am. Soc. Mass Spectrom. 2002, 13, 1341-1348.

25. Pfenninger, A.; Karas, M.; Finke, B.; Stahl, B. Structural Analysis of Underivatized Neutral Human Milk Oligosaccharides in the Negative Ion Mode by Nano-Electrospray MS ${ }^{\mathrm{n}}$. Part 1. Methodology. J. Am. Soc. Mass Spectrom. 2002, 13, 1331-1340.

26. Li, D. T.; Her, G. R. Linkage Analysis of Chromophore-Labeled Disaccharides and Linear Oligosaccharides by Negative Ion Fast Atom Bombardment Ionization and Collisional-Induced Dissociation with B/E Scanning. Anal. Biochem. 1993, 211, 250-257.

27. Seymour, J. L.; Costello, C. E.; Zaia, J. The Influence of Sialylation on Glycan Negative Ion Dissociation and Energetics. J. Am. Soc. Mass Spectrom. 2006, 17, 844-854.

28. Dell, A.; Morris, H. R.; Egge, H.; von Nicolai, H.; Strecker, G. Fast-Atom Bombardment Mass Spectrometry for Carbohydrate Structure Determination. Carbohydr. Res. 1983, 115, 41-52.

29. Dell, A.; Oates, J. E.; Morris, H. R.; Egge, H. Structure Determination of Carbohydrates and Glycosphingolipids by Fast Atom Bombardment Mass Spectrometry. Int. J. Mass Spectrom. Ion Phys. 1983, 46 415-418.

30. Egge, H.; Dell, A.; Von Nicolai, H. Fucose Containing Oligosaccharides from Human Milk. I. Separation and Identification of New Constituents. Arch. Biochem. Biophys. 1983, 224, 235-253.

31. Carr, S. A.; Reinhold, V. N. Structural Characterization of Sulfated Glycosaminoglycans by Fast Atom Bombardment Mass Spectrometry: Application to Chondroitin Sulfate. J. Carbohydr. Chem. 1984, 3, 381-401.

32. Saad, O. M.; Leary, J. A. Delineating Mechanisms of Dissociation for Isomeric Heparin Disaccharides Using Isotope Labeling and Ion Trap Tandem Mass Spectrometry. J. Am. Soc. Mass Spectrom. 2004, 15, $1274-1286$.

33. Wilm, M. S.; Mann, M. Electrospray and Taylor-Cone Theory, Dole's Beam of Macromolecules at last? Int. J. Mass Spectrom. Ion Processes. 1994, 136, 167-180.

34. Cancilla, M. T.; Penn, S. G.; Carroll, J. A.; Lebrilla, C. B. Coordination of Alkali Metals to Oligosaccharides Dictates Fragmentation Behavior in Matrix Assisted Laser Desorption Ionization/Fourier Transform Mass Spectrometry. J. Am. Chem. Soc. 1996, 118, 6736-6745.

35. Wysocki, V. H.; Tsaprailis, G.; Smith, L. L.; Breci, L. A. Mobile and Localized Protons: A Framework for Understanding Peptide Dissociation. J. Mass Spectrom. 2000, 35, 1399-1406. 